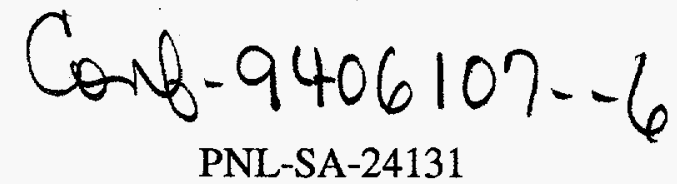

DOSIMETRIC APPLICATIONS OF THE NEW ICRP LUNG MODEL

A. C. James

June 1994

Presented at the

Health Physics Society Summer School Conference

June 20-24, 1994

Davis, California

Prepared for

the U.S. Department of Energy

under Contract DE-AC06-76RLO 1830

Pacific Northwest Laboratory

Richland, Washington 99352

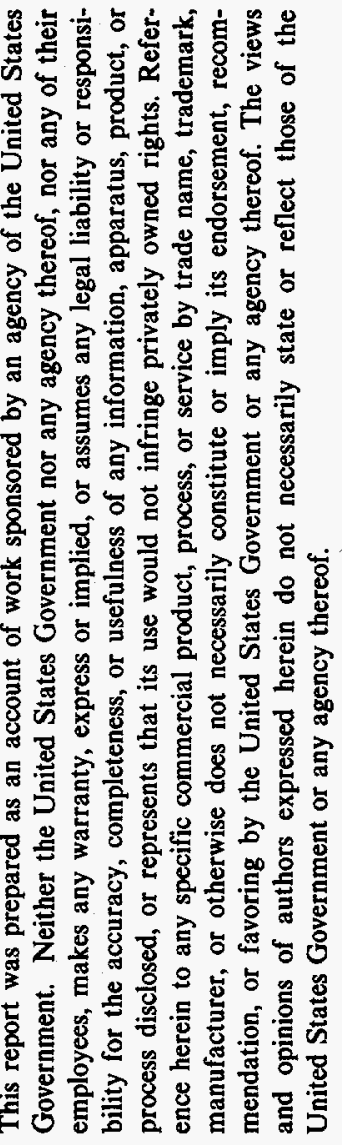




\section{DISCLAIMER}

Portions of this document may be illegible in electronic image products. Images are produced from the best available original document. 
To be published in Internal Radiation Dosimetry. Proceedings of 1994 Health Physics Society Summer School, University of California, Davis, June 20 - 24, 1994.

\title{
DOSIMETRIC APPLICATIONS OF THE NEW ICRP LUNG MODEL
}

Anthony C. James

Battelle Pacific Northwest Laboratories

Richland, Washington

\begin{abstract}
The International Commission on Radiological Protection (ICRP) has adopted a new dosimetric model of the human respiratory tract, to be issued as ICRP Publication 66. This chapter presents a summary of the main features of the new model. The model is a general update of that in Publication 30, but is significantly broader in scope. It applies explicitly to workers and all members of the public: for inhalation of particles, gases and vapors; evaluation of dose per unit intake or exposure; and interpretation of bioassay data. The approach is fundamentally different from the Publication 30 model which calculates only the average dose to the lungs. The new model takes account of differences in radiosensitivity of respiratory tract tissues, and the wide range of doses they may receive, and calculates specific tissue doses. The model readily incorporates specific information related to the subject (age, physical activity, smoking or health status) or the exposure (aerosol size and chemical form). The application of the new model to calculate equivalent lung dose and effective dose per unit intake is illustrated for several $\alpha$ - and 6 -emitting radionuclides, and the new values obtained are compared with those given by the ICRP Publication 30 lung model.
\end{abstract}




\section{INTRODUCTION}

The new ICRP Human Respiratory Tract Model for Radiological Protection, which is recommended in Publication 66 (ICRP, 1994), generally updates that used in Publication 30 (ICRP, 1979) for adult workers. However, the new model is broader in scope, having been designed not only to evaluate secondary limits on intake of radionuclides by inhalation for a reference worker, but also to:

provide a realistic framework for modeling lung retention and excretion characteristics in an individual case, and the resulting lung and systemic organ doses, based on bioassay data;

ㅁ take account of factors such as cigarette smoking and lung disease which influence lung retention;

- enable knowledge of the dissolution and absorption behavior of specific materials to be used in the calculation of lung dose, systemic absorption and excretion;

․ apply explicitly to all members of the population, giving reference values for children aged 3 months, 1, 5, 10 and 15 years, and for adults;

apply to gases and vapors as well as particles, and in all cases;

calculate biologically meaningful doses in a manner that is consistent with the morphological, physiological, and radiobiological characteristics of the various tissues of the respiratory tract.

The new model is fundamentally different from that in Publication 30, which calculates only the average dose to the lungs: it takes account of the differences in radiosensitivity of respiratory tract tissues, and the wide range of doses they may receive, and calculates doses to specific 
tissues. The respiratory tract is represented by five regions (Figure 1), based principally on radiobiological considerations, but also taking account of differences in function, particle deposition and clearance characteristics. Detailed consideration is given to the "inhalability" of aerosol particles, which depends on their aerodynamic size, and to the particle deposition and clearance characteristics of the nasal and oral passageways. These are termed the "extrathoracic" (ET) airways. The lungs themselves are divided into three "thoracic" regions, the Bronchial region (denoted by $\mathrm{BB}$ ), the Bronchiolar region (bb), and the Alveolar-Interstitial region (AI, the gas exchange region). Lymphatics are associated with both the extrathoracic and thoracic airways ( $\mathrm{LN}_{\mathrm{ET}}$ and $\mathrm{LN}_{\mathrm{TH}}$, respectively). The model is designed to evaluate the risks of lung and other cancers by first calculating the doses received by identified target tissues within each region, and then weighting and summing the constituent doses to give the "equivalent" doses to the extrathoracic airways and to the lungs as a whole. The tissue weighting factors recommended by ICRP in Publication 60 (ICRP, 1991) are then applied to these "equivalent" tissue doses to evaluate the associated risks.

The new model was developed by an ICRP Task Group ${ }^{1}$ which commenced its work in 1984. The model is based on extensive reviews of the available information on respiratory tract morphology, physiology, deposition, clearance, and radiation effects. These reviews are published as Annexes to the main report (ICRP, 1994). They provide the justification for the modeling approach and the reference values chosen, and also information about the uncertainty and variability associated with the model's parameters. The Task Group's final model was formally adopted for radiological protection purposes by ICRP at its April 1993 meeting. This chapter outlines the main features of ICRP's new respiratory tract model, and illustrates its application to the calculation of effective dose from exposure to aerosols of various $\alpha$ - and $\beta$ emitting radionuclides.

${ }^{1}$ Members of the Task Group were W.J. Bair (Chairman), M.R. Bailey, F.T. Cross, R.G. Cuddihy, P. Gehr, A.C. James, J.R. Johnson, R. Masse, M. Roy, and W. Stahlhofen. 


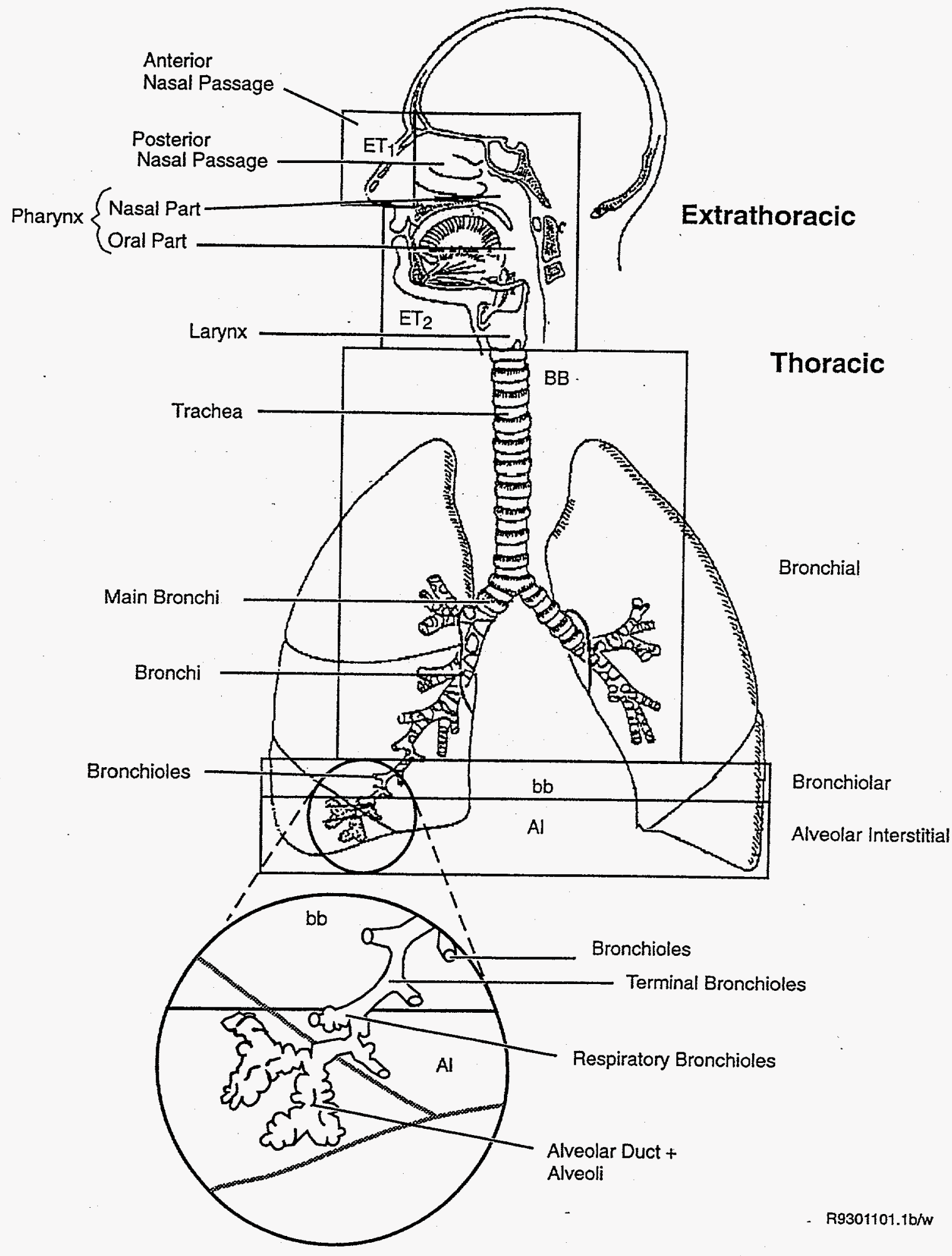

FIGURE 1. Anatomical regions of the respiratory tract. 


\section{TISSUES AND CELLS AT RISK}

Knowledge of the effects of radiation on the respiratory tract, from both animal experiments and from studies of irradiated human populations, has identified tissues and cells most likely to respond to irradiation from inhaled radionuclides. The model places emphasis on evaluating the risks of lung and other cancers. The target cells identified are the basal cells of the epithelium in the ET region; basal and secretory cells in the bronchial epithelium; Clara cells (a type of secretory cell) in the bronchiolar epithelium; and endothelial cells such as those of capillary walls and type II epithelial cells in the AI region. Reference dimensions of target tissues in each region, that are used for dosimetry, are given in Table 1. These values of tissue thickness and target cell depth are assumed to be the same in all subjects (adult and child).

TABLE 1. Dimensions of target tissues (assumed to be same in all people).

\begin{tabular}{|c|c|c|c|c|}
\hline Tissue & Target Cells & $\begin{array}{c}\text { Mucus } \\
\text { Thickness, } \\
\mu \mathrm{m}\end{array}$ & $\begin{array}{c}\text { Epithelial } \\
\text { Thickness, } \\
\mu \mathrm{m}\end{array}$ & $\begin{array}{l}\text { Depth of } \\
\text { Target Cell } \\
\text { Nuclei, } \mu \mathrm{m}\end{array}$ \\
\hline $\mathrm{ET}_{1}$ & Basal & - & 50 & $40-50$ \\
\hline $\mathrm{ET}_{2}$ & Basal & 15 & 50 & $40-50$ \\
\hline $\mathrm{BB}_{\mathrm{sec}}{ }^{(\mathrm{a})}$ & Secretory & 5 & 55 & $10-40$ \\
\hline $\mathrm{BB}_{\text {bas }}{ }^{(\mathrm{a})}$ & Basal & 5 & 55 & $35-50$ \\
\hline $\mathrm{bb}$ & Secretory & 2 & 15 & 4-12 \\
\hline $\mathrm{AI}$ & $\begin{array}{l}\text { Clara and type II alveolar } \\
\text { cells }\end{array}$ & - & - & (b) \\
\hline $\begin{array}{c}\mathrm{LN}_{\mathrm{ET}} \text { and } \\
\mathrm{LN}_{\mathrm{TH}}\end{array}$ & $\begin{array}{l}\text { Lymphocytes, endothelial, } \\
\text { and germinal center cells }\end{array}$ & - & - & (b) \\
\hline
\end{tabular}

(a) $\mathrm{BB}_{\mathrm{sec}}$ is the mass of bronchial epithelium through which secretory cell nuclei are distributed, and $\mathrm{BB}_{\text {bas }}$ that for basal cell nuclei.

(b) Average dose to region calculated. 


\section{PHYSIOLOGY AND EXPOSURE PARAMETERS}

A major advance of the new model over that of Publication 30 is that the intake of different subjects (adults and children) is represented in terms of a given exposure (time-integrated air concentration), for various levels of physical activity. Thus, the doses per unit exposure which are generally required in dose assessments can be calculated, as well as doses per unit intake. Two factors relate intake to exposure: inhalability and breathing rate.

Inhalability is the ratio of the concentration in air entering the respiratory tract to that in the ambient air. The inertia of particles larger than a few microns reduces the concentration in air entering the nose or mouth (unless the subject is facing into a strong wind). The net effect is to reduce the inhalability of particles of aerodynamic diameter larger than about $20 \mu \mathrm{m}$ to about $50 \%$ for wind speeds less than about $2 \mathrm{~m} \mathrm{~s}^{-1}$. For convenience, inhalability is represented as an algebraic function of particle aerodynamic diameter and wind speed, and is incorporated in the deposition model.

․ Breathing rate (frequency and volume) is the main factor in the model that depends on age and physical activity, and there are comprehensive data relating to women and children as well as adult males. Reference values of volumetric breathing volume and frequency are recommended for male and female adults, and for children aged 15, 10, 5 , and 1 year, and 3 months, for various levels of activity: resting, sitting, light and heavy exercise. These have been combined with habit survey data to give reference volumes inhaled per working shift or per day. For example, a "reference male worker" is assumed to spend $31 \%$ of an 8-hour work period "sitting" and $69 \%$ at "light exercise," giving a mean ventilation rate of $1.2 \mathrm{~m}^{3} \mathrm{~h}^{-1}$. Account is also taken of the different partitioning of airflow between the nose and mouth in "normal nose-breathers" and "habitual mouth-breathers."

The modeled aerosol inhalability and breathing rates determine the intake for a given exposure, and are used with the deposition model to determine regional deposition. 


\section{DEPOSITION}

The deposition model evaluates fractional deposition of an aerosol in each region, for all possible aerosol sizes $(0.0006-100 \mu \mathrm{m})$. Deposition in the ET regions was determined empirically. Measured deposition was related to characteristic parameters of particle size and airflow. Deposition efficiencies determined experimentally in men were scaled by anatomical dimensions to predict deposition in women and children. For the thoracic airways a theoretical model of gas transport and particle deposition(Egan et al., 1989) was used to calculate particle deposition in each of the $\mathrm{BB}, \mathrm{bb}$, and $\mathrm{AI}$ regions, and to quantify the effects of the subject's lung size and breathing rate. To model particle deposition, the regions were treated as a series of filters, during both inhalation and exhalation. The efficiency of each filter was evaluated by considering aerodynamic processes (gravitational settling, inertial impaction) and thermodynamic processes (diffusion), acting competitively. The resulting total deposition in each region of the respiratory tract in different subjects is represented by algebraic formulae, expressed in terms of particle size, breathing rates, standard lung volumes, and scaling factors for airway dimensions.

Publication 66 gives deposition fractions calculated for aerosols having lognormal particle size distributions, with geometric standard deviations $\left(\sigma_{\mathrm{g}}\right)$ taken to be a function of the median particle size, increasing from a value of 1.0 at $0.0006 \mu \mathrm{m}$ to 2.5 at $1 \mu \mathrm{m}$ and above. Figure 2 shows the values for a reference nose-breathing worker. In general, regional deposition is lower than corresponding values given by the Publication 30 model. Deposition in ET is similar to that in the Publication $30 \mathrm{NP}$ region up to about $5 \mu \mathrm{m}$ Activity Median Aerodynamic Diameter (AMAD), but then decreases with decreasing inhalability. Deposition in $\mathrm{BB}$ and bb together come to only about half the TB deposition. Similarly, AI deposition is considerably lower than $\mathrm{P}$ deposition below $5 \mu \mathrm{m}$.

Publication 66 gives corresponding curves for each population group (including habitual mouth breathers) at the various levels of activity, taking account of oro-nasal breathing during heavy exercise. The model can also account for the effects on regional deposition of the growth of hygroscopic particles in the humid air of the respiratory tract. 

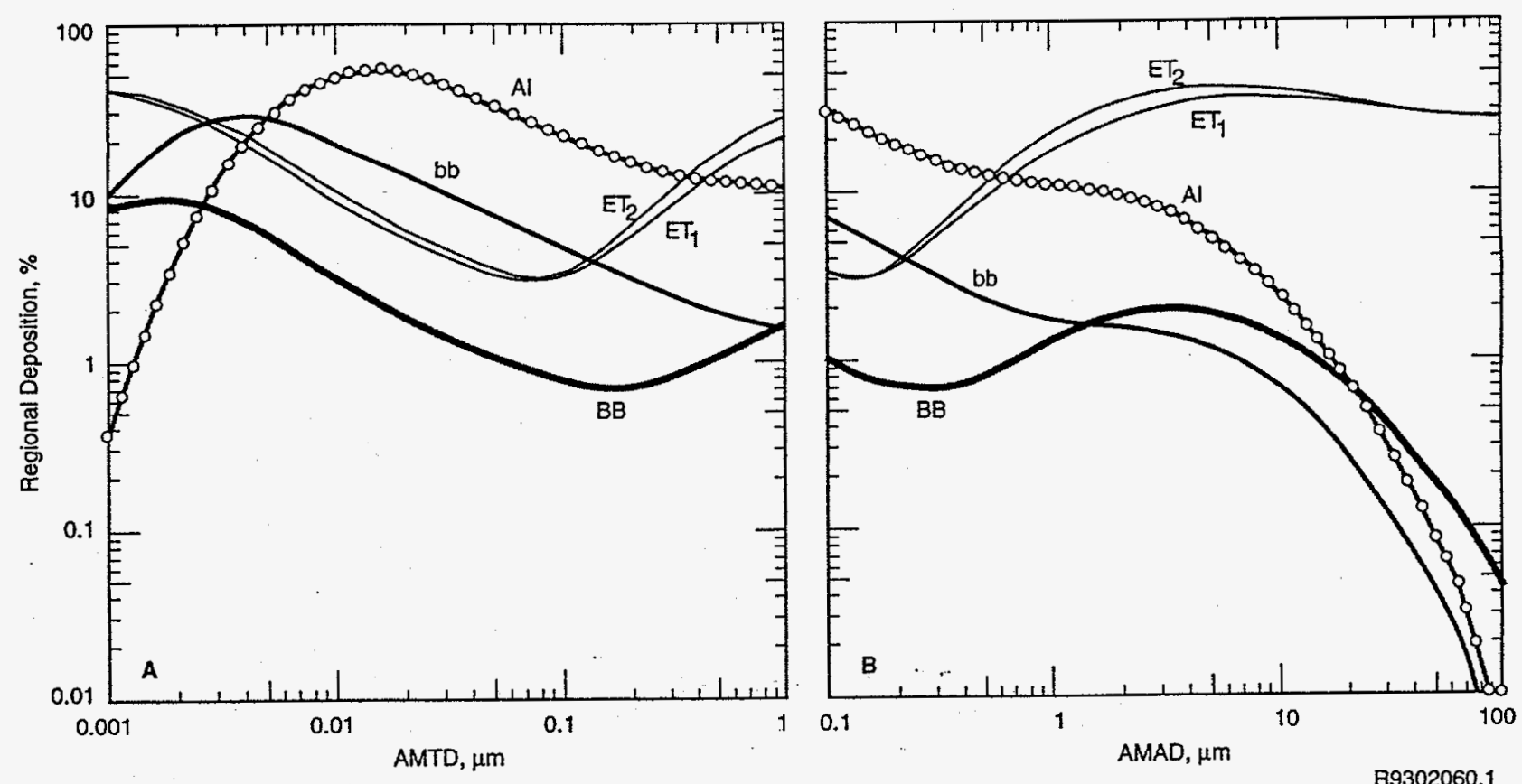

FIGURE 2. Fractional deposition in each region of the respiratory tract for a reference worker (normal nose-breather) shown as functions of (A) the activity median thermodynamic diameter, AMTD, and (B) the activity median aerodynamic diameter, AMAD (for particles of density 3.0 $\mathrm{g} \mathrm{cm}^{-3}$ and shape factor 1.5).

\section{GASES AND VAPORS}

The Publication 66 model can be applied to inhalation of gases and vapors, but unlike the deposition of non-hygroscopic particles, respiratory tract retention then depends on the chemical behavior of the inhaled material. Inhaled gas molecules readily contact airway surfaces, but are usually re-entrained in the air unless they dissolve in, or react with, the surface lining. The fraction of an inhaled gas or vapor that is retained in, or absorbed from, each respiratory tract region thus depends on its solubility and reactivity and, except in simple cases, has to be treated on an individual basis. The model assigns gases and vapors to three classes:

SR-0. Insoluble and non-reactive. Examples are $\mathrm{H}_{2}$ and $\mathrm{SF}_{6}$. Internal doses can be calculated assuming the airways are uniformly filled with gas at the ambient 
concentration, since doses from absorbed gas are negligible. In many cases external radiation from the surrounding cloud dominates exposure.

SR-1. Soluble or reactive. Examples are $\mathrm{O}_{3}, \mathrm{NO}_{2}$ and $\mathrm{H}_{2} \mathrm{O}$. These gases or vapors give exposure to all airways, and also absorption into tissues and blood. They require individual evaluation. Publication 66 recommends that in the absence of specific information, the conservative assumption of $100 \%$ total deposition is made, with a default distribution of $10 \%$ in $\mathrm{ET}_{1}, 20 \%$ in $\mathrm{ET}_{2}, 10 \%$ in $\mathrm{BB}, 20 \%$ in bb and $40 \%$ in $\mathrm{AI}$.

SR-2. Highly soluble and reactive. Examples are $\mathrm{SO}_{2}$ and $\mathrm{HF}$. These are completely absorbed by tissues and blood in the ET regions.

\section{CLEARANCE}

The new model describes three clearance pathways. Material deposited in $\mathrm{ET}_{1}$ is removed by extrinsic means such as nose-blowing. In other regions, clearance is competitive between particle transport to the GI tract and lymphatics, and absorption into blood. It is assumed that particle transport rates are the same for all materials. Absorption into blood is material specific and is assumed to occur at the same rate in all regions except $\mathrm{ET}_{1}$, where none occurs. Fractional clearance rates vary with time. However, to facilitate calculations these are represented by combinations of compartments that clear at constant rates. It is assumed that both particle transport and absorption rates are independent of age and gender.

\section{Particle transport}

Figure 3 shows the compartment model for particle transport. Rate constants shown are reference values, in $\mathrm{d}^{-1}$. As far as possible, these were derived from human studies, since particle transport rates are known to vary greatly between mammalian species. 


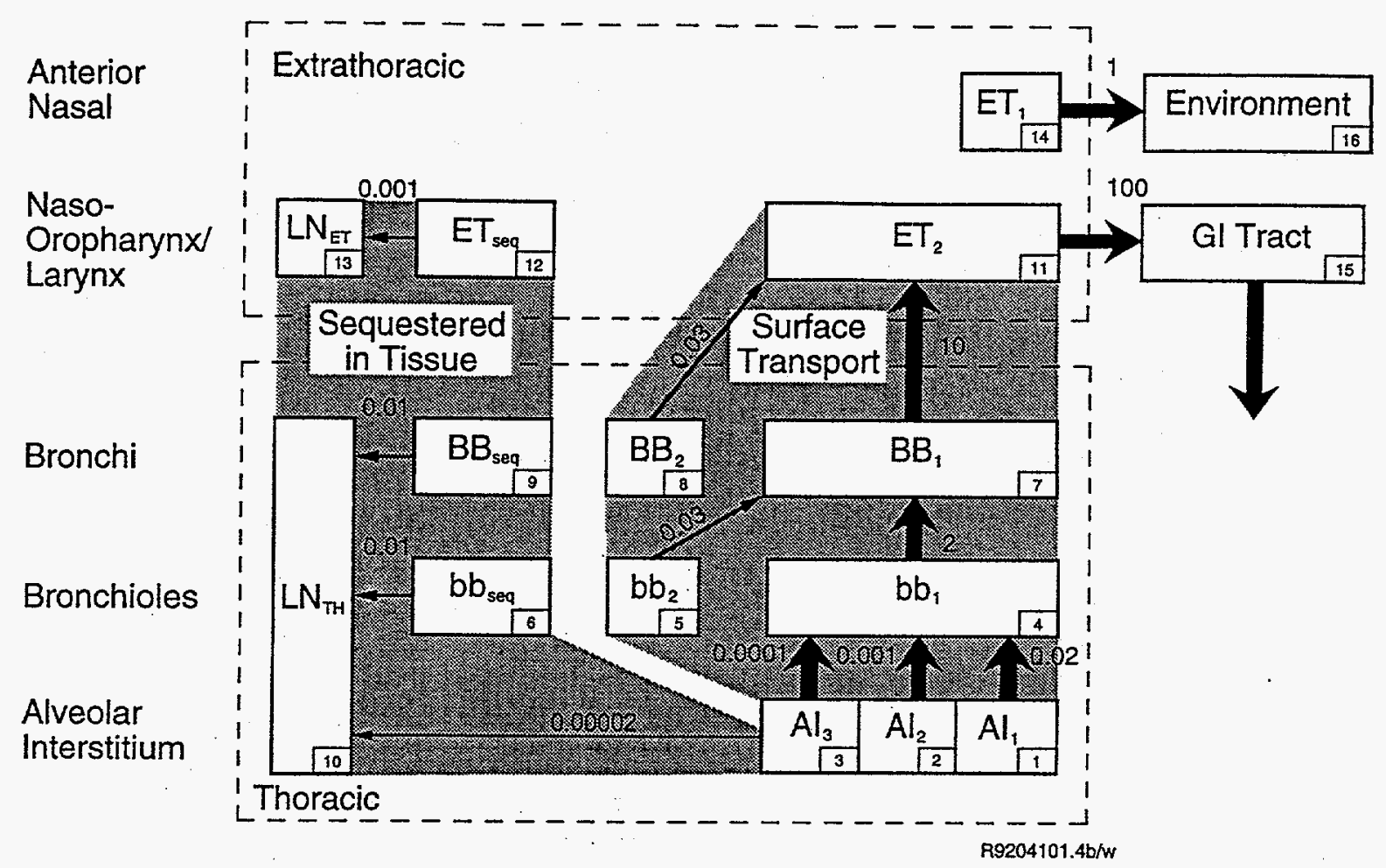

FIGURE 3. Compartmental model to represent time-dependent particle transport from each region of the respiratory tract. Particle transport rate constants shown beside the arrows are reference values in $\mathrm{d}^{-1}$. Compartment numbers (shown in the lower right-hand corner of each compartment box) are used to define clearance pathways. Thus the particle transport rate from $\mathrm{bb}_{1}$ to $\mathrm{BB}_{1}$ is denoted $\mathrm{m}_{4,7}$, and has the value $2 \mathrm{~d}^{-1}$.

Most material deposited in the anterior nasal passage $\left(\mathrm{ET}_{1}\right)$ is removed by extrinsic means in about a day. The remaining airways of the head and neck $\left(\mathrm{ET}_{2}\right)$ are covered by a fluid lining which is cleared to the pharynx and swallowed in a few minutes. However, evidence from animal experiments indicates that a small fraction of particles deposited in the nasal passage is subject to prolonged retention in the epithelium. This is represented by the sequestration compartment $\mathrm{ET}_{\text {seq, }}$, from which material clears to regional lymphatics $\left(\mathrm{LN}_{\mathrm{ET}}\right)$. Although sequestered particles amount to less than $0.1 \%$ of the material deposited in $\mathrm{ET}_{2}$, their contribution to dose needs to be considered because they are retained for a long time. 
Much of the material deposited in BB and bb is cleared rapidly (within hours) by mucus. Recent human studies, however, indicate that a large fraction of material deposited in BB and bb clears slowly (weeks): about $50 \%$ for particles smaller than a few $\mu \mathrm{m}$ diameter, but this decreases with increasing size. The slowly cleared material is represented by compartments $\mathrm{BB}_{2}$ and $\mathrm{bb}_{2}$. There is evidence from both animal and human studies for retention in the airway wall in BB and $b b$, which is represented by $\mathrm{BB}_{\text {seq }}$ and $b b_{\text {seq. }}$. The fraction assumed to be retained is greater than in ET, at about $0.5 \%$, but with a shorter retention time.

Human experimental data show that in the $\mathrm{AI}$ region there is about $80 \%$ retention at 50 days and $50 \%$ at a year. In vivo and autopsy measurements, following accidental intakes, show that there is some very long term retention in the lungs. This is represented by three compartments, with $30 \%$ in the $30-\mathrm{d}$ compartment, $10 \%$ in the very long-term (7000-d) compartment, and the balance in the 700-d compartment. Autopsy studies also show that at many years after intake the concentration in lymph nodes is about 20 times that in the lungs (for nonsmokers). This observation was used to determine the rate of transfer from $\mathrm{AI}$ to $\mathrm{LN}_{\mathrm{TH}}$.

\section{Absorption}

Absorption to blood is a two-stage process: (1) dissociation of particles into material that can be absorbed into blood (dissolution); and (2) absorption into blood of soluble material and of material dissociated from particles (uptake). Both stages can be time-dependent.

The simplest compartment model representation of time-dependent dissolution is to assume that a fraction $\left(f_{r}\right)$ dissolves relatively rapidly, at a rate $s_{r}$, and the remaining fraction $\left(1-f_{r}\right)$ dissolves more slowly, at a rate $s_{s}$ (Figure $4 a$ ). For simplicity, the Publication 66 model provides for two such states, since there is rarely in practice sufficient information to justify more. A limitation of this system, however, is that it can only readily represent an overall fractional dissolution rate that decreases with time. To overcome this, the Publication 66 model uses an equivalent system with the same number of variables shown in Figure $4 \mathrm{~b}$. In this system, the particles in their "initial" state dissolve at a constant rate $s_{p}$, but are simultaneously 
converted to a "transformed" state (at a rate $s_{\mathrm{p}}$ ), in which they have a different dissolution rate $\mathrm{s}_{\mathrm{t}}$. This provides the same results as the system in Figure $4 \mathrm{a}$, with the following values:

$$
\begin{aligned}
& s_{p}=s_{s}+f_{r}\left(s_{r}-s_{s}\right) \\
& s_{p t}=\left(1-f_{r}\right)\left(s_{r}-s_{s}\right) \\
& s_{t}=s_{s}
\end{aligned}
$$

(a)

Regional Deposition

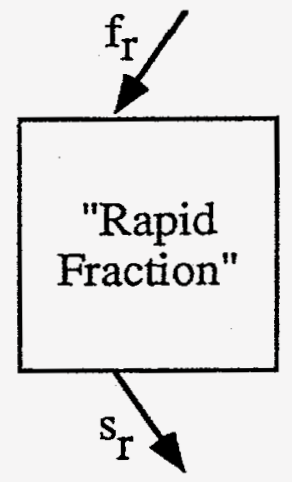

Absorption into Blood (b)

Regional Deposition

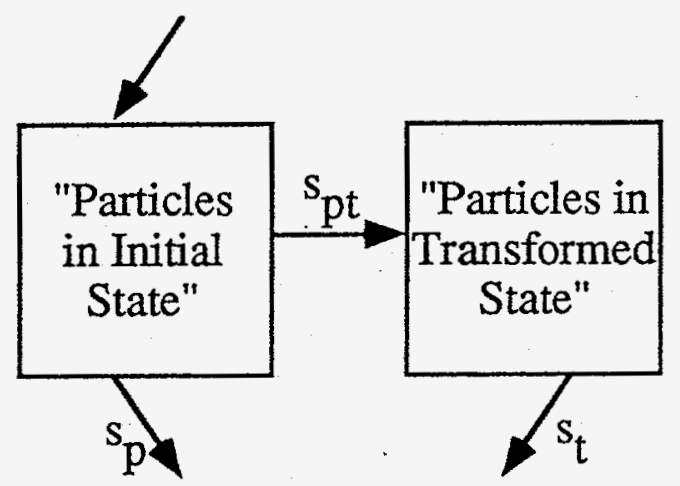

Absorption into Blood

FIGURE 4. Alternative compartment models for time-dependent dissolution.

With this system, the initial dissolution rate is approximately $s_{p}$ and the final dissolution rate is approximately $s_{t}$. Thus with suitable choice of parameters, including $s_{t}>s_{p}$, an increasing dissolution rate can be represented. This is useful, for example, to represent the unusual fragmentation behavior and increasing rate of dissolution of highly radioactive ${ }^{238} \mathrm{PuO}_{2}$ particles.

Ideally the absorption rate of any important material should be determined from a study of the material itself. A major advantage of the model structure in treating clearance as competion between particle transport and absorption, is that it is simple to incorporate experimentally 
measured absorption rates, especially if they can be represented in terms of either set of absorption parameters given above.

If, for some specific materials, it will be necessary to represent time-dependent uptake, the Publication 66 model can also treat a fraction $\left(\mathrm{f}_{\mathrm{b}}\right)$ of the dissolved material as being retained in a "bound" state, from which it goes into blood at a rate $s_{b}$, while the remaining fraction $\left(1-f_{b}\right)$ goes to blood instantaneously. Material in the "bound" state is not cleared by particle transport processes. Thus, only one "bound" compartment is required for each region.

\section{Default absorption rates}

In the absence of empirically determined absorption rates for specific compounds, default values are recommended for three material "Types": F (fast), $M$ (moderate) and $S$ (slow). These correspond to Classes D, W, and Y, respectively, in the Publication 30 system. Recommended values for each are specified in terms of the parameters $s_{p}, s_{p t}$ and $s_{t}$, and are given in Table 2 . Note that the "bound" state is not employed in the defaults, and thus for all three Types $f_{b}=$ 0 . These absorption rates, expressed as approximate half-times, and the corresponding amounts of material deposited in each region that reaches the blood are summarised as follows:

Type F: $100 \%$ at 10 minutes. There is rapid absorption of almost all material deposited in $\mathrm{BB}, \mathrm{bb}$, and $\mathrm{AI}$, and $50 \%$ of material deposited in $\mathrm{ET}_{2}$.

q Type $M: 10 \%$ at 10 minutes; $90 \%$ at $140 \mathrm{~d}$. There is rapid absorption of about $10 \%$ of the deposit in $\mathrm{BB}$ and $\mathrm{bb}$; and $5 \%$ of material deposited in $\mathrm{ET}_{2}$. About $70 \%$ of the deposit in AI reaches the blood eventually.

․ Type S: $0.1 \%$ at 10 minutes; $99.9 \%$ at $7000 \mathrm{~d}$. There is little absorption from ET, BB, or bb, and about $20 \%$ of the deposit in AI reaches the blood eventually. 
In the forthcoming revision of ICRP's Publication 30 information relating to respiratory tract absorption of each element of radiological importance will be reviewed. Where sufficient information is available, absorption rates for important compounds will be recommended. Other compounds will be assigned to the three absorption Types. In the meantime, compounds classed as D, W or $\mathrm{Y}$ in Publication 30 are assigned to types F, M or S respectively. Note, however, that whereas the $\mathrm{D}, \mathrm{W}$ and $\mathrm{Y}$ parameters define overall clearance, the $\mathrm{F}, \mathrm{M}$ and $\mathrm{S}$ parameters relate only to absorption to blood. Particle transport rates to the GI tract and lymphatics are the same for all three absorption Types.

TABLE 2. Default absorption parameters for Type F, M and S materials.

\begin{tabular}{lccc}
\hline \multicolumn{1}{c}{$\begin{array}{c}\text { Publication 30 Class } \\
\text { Type of Absorption Behavior }\end{array}$} & $\begin{array}{c}\text { D (days) } \\
\text { F (fast) }\end{array}$ & $\begin{array}{c}\text { W (weeks) } \\
\text { M (moderate) }\end{array}$ & $\begin{array}{c}\text { Y (years) } \\
\text { S (slow) }\end{array}$ \\
\hline $\begin{array}{l}\text { Fraction dissolved rapidly } \\
\mathrm{f}_{\mathrm{r}}\end{array}$ & 1.0 & 0.1 & 0.001 \\
$\begin{array}{l}\text { Approx. Dissolution rate: rapid, } \mathrm{d}^{-1} \\
\mathrm{~s}_{\mathrm{r}}\end{array}$ & 100 & 100 & 100 \\
$\begin{array}{l}\text { Approx. Dissolution rate: slow, } \mathrm{d}^{-1} \\
\mathrm{~s}_{\mathrm{s}}\end{array}$ & - & 0.005 & 0.0001 \\
\hline
\end{tabular}

\section{DOSIMETRY}

In accordance with the ICRP's general approach, the dose to each region of the respiratory tract is given by the average dose to the target tissue in that region. The target cells identified in $\mathrm{ET}_{1}, \mathrm{ET}_{2}, \mathrm{BB}$ and $\mathrm{bb}$, and dimensions that define the mass of tissue containing target cells in each of these regions for dose calculations, are given in Table 1. In each of these regions there are also several possible sources. In $b b$, for example, activity in the fast phase of clearance $\left(b_{1}\right.$, Figure 3$)$ is taken to be in the mucus layer above the cilia; activity 
in the slow phase of clearance $\left(\mathrm{bb}_{2}\right)$ is taken to be in the mucus between the cilia; particles retained in the airway wall $\left(b_{\text {seq }}\right)$ are taken to be in a macrophage layer at a depth of 20-25 $\mu \mathrm{m}$ (i.e., below the target cells); activity "bound" to the epithelium is uniformly distributed in it; and account also has to be taken of irradiation from activity present in the AI region. For each source/target combination, Publication 66 provides absorbed fractions for nonpenetrating radiations: $\alpha, \beta$ and electrons; in each case as a function of energy. To obtain these, a single cylindrical geometry was used to represent each region: the representative bronchus for $\mathrm{BB}$ being $5 \mathrm{~mm}$ diameter and the representative bronchiole for bb $1 \mathrm{~mm}$ diameter.

As an example, Figure 5 shows the absorbed fractions calculated as a function of emitted $\alpha$ particle energy for bronchial (BB) target tissue containing secretory cells. Different values are obtained for each of the different source compartments within the $\mathrm{BB}$ region, i.e., fast mucus, slow mucus, sequestered or bound tissue compartments. In general, the values of absorbed fraction calculated for the target tissue containing basal cells are smaller (except for "sequestered" $\alpha$-emitters of low energy). The corresponding masses of these target tissues, together with the other target tissue masses used to calculate regional tissue doses for an adult male, are given in Table 3. In other subjects, the masses of ET, BB and bb tisues are scaled in proportion to airway surface area, and those of $\mathrm{AI}$ and $\mathrm{LN}$ in proportion to body weight.

TABLE 3. Masses of target tissues in the adult male.

\begin{tabular}{|c|c|c|c|c|c|c|c|}
\hline \multicolumn{8}{|c|}{ Mass, $\mathrm{kg}$} \\
\hline $\mathrm{ET}_{1}$ & $\mathrm{ET}_{2}$ & $\mathrm{BB}_{\mathrm{sec}}^{(\mathrm{a})}$ & $\mathrm{BB}_{\mathrm{bas}}^{(a)}$ & bb & $\mathrm{AI}^{(\mathrm{b})}$ & $\mathrm{LN}_{\mathrm{ET}}{ }^{(\mathrm{c})}$ & $\mathrm{LN}_{\mathrm{TH}}{ }^{(\mathrm{c})}$ \\
\hline $2.010^{-5}$ & $4.510^{-4}$ & $8.710^{-4}$ & $4.310^{-4}$ & $2.010^{-3}$ & 1.1 & $1.510^{-2}$ & $1.510^{-2}$ \\
\hline
\end{tabular}

(a) $\mathrm{BB}_{\text {sec }}$ is the mass of bronchial epithelium through which secretory cell nuclei are distributed, and $\mathrm{BB}_{\text {bas }}$ that for basal cell nuclei. 
(b) Including blood, excluding lymph nodes.

(c) Mass of lymphatic tissue is assumed to be the same in extrathoracic and thoracic regions.

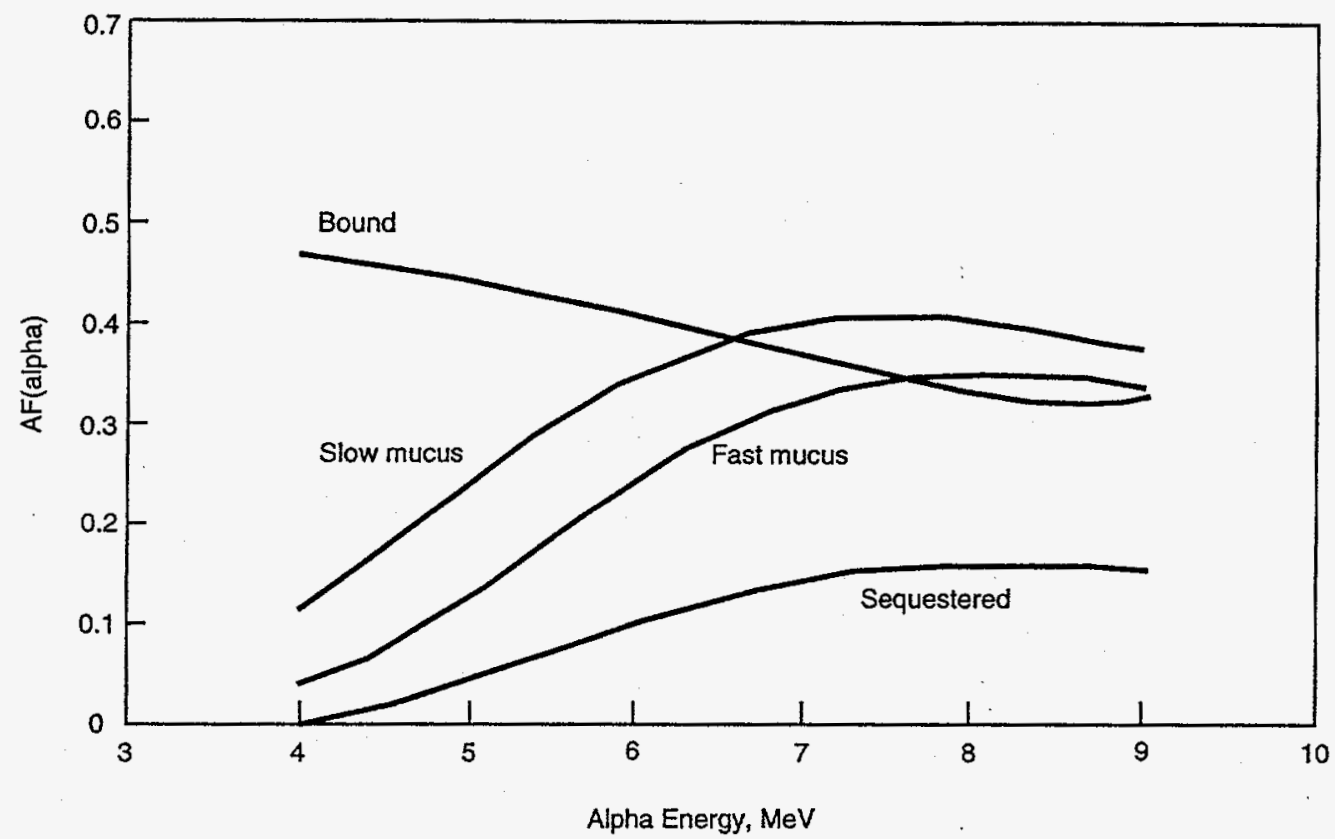

R9207093.3

FIGURE 5. Absorbed fractions for secretory cell targets from $\alpha$ emissions in the bronchial (BB) region. Curves are shown for emissions in the mucous gel layer (fast mucus), sol layer (slow mucus), the epithelium itself (bound source), and the lamina propria (sequestered source).

To take account of differences in sensitivity between tissues, each regional dose is multiplied by a factor, $A_{i}$, representing the region's sensitivity relative to that of the whole organ. The weighted sum is the equivalent dose to the extrathoracic or thoracic airways (the lungs) respectively:

$$
\begin{aligned}
& H_{T}(E T)=H_{T, E T} A_{E T_{1}}+H_{T, E T} A_{E T}+H_{T, L N_{E T}} A_{L N_{E T}} \\
& H_{T}(T H)=H_{T, B B} A_{B B}+H_{T, b b} A_{b b}+H_{T, A T} A_{A l}+H_{T, L N_{T H}} A_{L N_{T H}}
\end{aligned}
$$

The risk apportionment factor applied to $\mathrm{ET}_{1}$ is a small fraction of that for the skin of the whole body, and is taken to be 0.001 . In the ET region, the risk is almost entirely to the posterior 
nose, pharynx and larynx, i.e., $\mathrm{ET}_{2}$, which is given an apportionment factor of 0.999 . Because of the difficulties associated with quantifying the relative sensitivity of each of the thoracic regions, the same factor, 0.333 , is assigned to $\mathrm{BB}, \mathrm{bb}$ and $\mathrm{AI}$. This does, however imply far higher sensitivities per unit mass for $\mathrm{BB}$ and $\mathrm{bb}$ than for $\mathrm{AI}$, because of their much lower masses. In $\mathrm{BB}$, the factor 0.333 is applied to the average of the tissue doses calculated separately for secretory and basal cells.

The appropriate ICRP tissue weighting factors are applied to these equivalent organ doses to obtain their contributions to effective dose. The weighting factor 0.12 specified for lungs (ICRP, 1991a) is applied to the equivalent dose to the thoracic airways $H_{T}(T H)$. In forthcoming ICRP publications, the extrathoracic airways will be included in the list of remainder tissues and organs. A weighting factor of 0.025 will then be applied to the equivalent dose to the extrathoracic airways, $\mathrm{H}_{\mathrm{T}}(\mathrm{ET})$, when it exceeds the highest dose in any of the twelve organs for which a weighting factor is specified (ICRP, 1991b).

\section{SOFTWARE FOR SOLVING THE NEW MODEL}

A user-friendly LUng Dose Evaluation Program (LUDEP) for calculating doses and dose rates to regions of the respiratory tract and to other body organs from intakes of radionuclides using the Publication 66 lung model has been described by Birchall et al. (1991), and is available from the National Radiological Protection Board (NRPB), Chilton, U.K. (Jarvis et al., 1993). This program (run on a personal computer) includes two databases of radionuclide decay data and the biokinetic models presented in ICRP Publication 30. The version published in 1993 (LUDEP 1.0) contains biokinetic models and organ dosimetry data applicable only to adults, and does not encompass bioassay calculations. It can handle all radionuclides without, and some with, radioactive progeny. NRPB plans to make available more comprehensive versions of LUDEP when their development is completed. 


\section{EXAMPLES OF CALCULATED DOSE PER UNIT INTAKE}

To illustrate the degree to which the Publication 66 model could result in revision of ICRP's recommended values of dose per unit intake, I have compared here doses calculated for the "reference worker" using the new model with those calculated using the Publication 30 model. This comparison assumes that each of the various $\alpha$ - and $\beta$-emitting radionuclides considered will be assigned the default absorption Type F, M or S in place of the corresponding D, W or Y solubility classification in Publication 30. In some cases, however, e.g., for various forms of uranium and transuranic aerosols, the ICRP is likely to develop and apply more specific values of absorption rate constants to reevaluate dose conversion coefficients (and Annual Limits on Intake, ALIs).

In revising their reference dose conversions and ALIs for occupational exposure, ICRP will assume that a value of $5 \mu \mathrm{m} \mathrm{AMAD}$ is more generally representative than the $1 \mu \mathrm{m}$ AMAD assumed in Publication 30. For the purpose of direct comparison, however, I will show here the dose conversion coefficients calculated using the Publication 66 model for $1 \mu \mathrm{m}$ AMAD aerosols, as well as for the new recommendation of $5 \mu \mathrm{m}$ AMAD.

\section{Equivalent lung dose}

Table 4 compares equivalent doses to the lungs calculated using the Publication 30 model and ICRP's new respiratory tract model in Publication 66. The following general observations can be made.

․ For soluble forms of both $\alpha$ and $\beta$ emitters, the Publication 66 model generally predicts lower doses to the lungs, in some cases an order of magnitude lower.

ㅁ For moderately soluble forms of $\alpha$ and $\beta$ emitters, and for the longer-lived $\beta$ emitters, the new model predicts approximately twofold higher lung doses for $1-\mu \mathrm{m}$ AMAD 
aerosols than the Publication 30 model. However, for the recommended typical aerosol size of $5 \mu \mathrm{m}$ AMAD, the difference between the reference lung doses calculated using the new and old models are generally less than a factor of two. In some instances the new model gives lower doses.

For insoluble $\alpha$ and $\beta$ emitters, the new respiratory tract model predicts equivalent lung doses that are substantially lower than those given by the Publication 30 model. The predicted lung doses for the reference aerosol size of $5 \mu \mathrm{m}$ AMAD are generally fourto eightfold lower than the Publication 30 values for $1-\mu \mathrm{m}$ AMAD aerosols.

\section{Effective dose}

Table 5 compares the committed effective doses given by the old and new models. These include contributions from material translocated to other body organs; the amounts of material translocated are also determined by these models. In calculating the equivalent and effective doses contributed by other body organs, I have assumed here the biokinetic models given in Publication 30 (ICRP, 1979) and the tissue weighting factors recommended in Publication 60 (ICRP, 1991a). The following general observations can be made.

For soluble $\alpha$ and $\beta$ emitters, the new respiratory tract model tends to predict lower values of effective dose per unit intake than Publication 61.

For moderately soluble materials, the new model tends to predict effective doses similar to those of the Publication 61. Long-lived isotopes of the transuranium isotopes are an exception, where the new model gives values of effective dose for the reference $5 \mu \mathrm{m}$ AMAD that are approximately twofold lower than the corresponding values given in Publication 61. 
․ For insoluble forms of the radionuclides considered here, the new model gives effective doses that are two- to ninefold lower than the corresponding values given in Publication 61 (which are based on the Publication 30 lung model).

\section{ICRP'S APPLICATIONS OF THE NEW LUNG MODEL}

Committee 2 of ICRP is currently revising Publication 61 (Annual Limits on Intakes of Radionuclides by Workers Based on the 1990 Recommendations) to incorporate new values of dose per unit intake calculated using the Publication 66 respiratory tract model. In due course, a complete revision of Publication 30 will be issued, taking into account a new Reference Man report and revised biokinetic models. Complete revisions of Publication 54 (Individual Monitoring for Intakes of Radionuclides by Workers: Design and Implementation), and Publication 56 (Age-dependent Doses to Members of the Public from Intake of Radionuclides) are also in preparation.

Acknowledgement - The author's work with the ICRP Task Group on a Human Respiratory Tract Model for Radiological Protection was partially supported by the U.S. Department of Energy under Contract DE-AC06-76RLO 1830 with Battelle Memorial Institute. 
TABLE 4. Equivalent dose to the lungs given by the Publication 66 lung model compared with Publication 30 values.

\begin{tabular}{|c|c|c|c|c|c|c|}
\hline \multirow{3}{*}{$\begin{array}{l}\begin{array}{c}\text { Radio- } \\
\text { nuclide }\end{array} \\
\text { Po-210 }\end{array}$} & \multirow{3}{*}{$\frac{t_{1 / 2}}{138 d}$} & \multicolumn{5}{|c|}{ Equivalent Dose per Unit Intake ( $\mu$ Sv/Bq) } \\
\hline & & \multirow{2}{*}{\multicolumn{2}{|c|}{$\begin{array}{l}\text { Publication } 30 \text { Model } \\
\text { (by retention class) }\end{array}$}} & & \multicolumn{2}{|c|}{$\begin{array}{l}\text { Publication } 66 \mathrm{Model} \\
\text { (by solubility type and AMAD) }\end{array}$} \\
\hline & & & & & $1-\mu \mathrm{m}$ & $5-\mu \mathrm{m}$ \\
\hline Po-210 & $138 \mathrm{~d}$ & & $\begin{array}{l}0.72 \\
13\end{array}$ & $\begin{array}{l}\text { F: } \\
\text { M: } \\
\text { S: }\end{array}$ & $\begin{array}{l}0.22 \\
27 \\
36\end{array}$ & $\begin{array}{l}0.26 \\
20 \\
26\end{array}$ \\
\hline $\mathrm{U}-234$ & $244,500 \mathrm{y}$ & $\begin{array}{l}\text { D: } \\
\text { W: } \\
\text { Y: }\end{array}$ & $\begin{array}{c}0.31 \\
16 \\
290\end{array}$ & $\begin{array}{l}\text { F: } \\
\text { M: } \\
\text { S: }\end{array}$ & $\begin{array}{l}0.027 \\
27 \\
75\end{array}$ & $\begin{array}{l}0.027 \\
19 \\
44\end{array}$ \\
\hline Pu-239 & 24,000 y & $\begin{array}{l}\text { W: } \\
\text { Y: }\end{array}$ & $\begin{array}{c}17 \\
320\end{array}$ & $\begin{array}{l}\text { M: } \\
\text { S: }\end{array}$ & $\begin{array}{l}31 \\
84\end{array}$ & $\begin{array}{l}22 \\
50\end{array}$ \\
\hline Am-241 & $432 \mathrm{y}$ & W: & 18 & M: & 35 & 25 \\
\hline $\mathrm{Cm}-242$ & $163 \mathrm{~d}$ & W: & 15 & M: & 36 & 28 \\
\hline $\mathrm{Cm}-244$ & $18.1 \mathrm{y}$ & W: & 19 & M: & 39 & 29 \\
\hline P-32 & $14.3 \mathrm{~d}$ & $\begin{array}{l}\text { D: } \\
\text { W: }\end{array}$ & $\begin{array}{l}0.0025 \\
0.026\end{array}$ & $\begin{array}{l}\mathrm{F}: \\
\mathrm{M}:\end{array}$ & $\begin{array}{l}0.00029 \\
0.020\end{array}$ & $\begin{array}{l}0.00039 \\
0.014\end{array}$ \\
\hline Co-57 & $271 \mathrm{~d}$ & $\begin{array}{l}\text { W: } \\
\text { Y: }\end{array}$ & $\begin{array}{l}0.0040 \\
0.017\end{array}$ & $\begin{array}{l}\text { M: } \\
\text { S: }\end{array}$ & $\begin{array}{l}0.0027 \\
0.0058\end{array}$ & $\begin{array}{l}0.0016 \\
0.0033\end{array}$ \\
\hline Fe-59 & $44.6 \mathrm{~d}$ & $\begin{array}{l}\text { D: } \\
\text { W: }\end{array}$ & $\begin{array}{l}0.0035 \\
0.014\end{array}$ & $\begin{array}{l}\mathrm{F}: \\
\mathrm{M}:\end{array}$ & $\begin{array}{l}0.0016 \\
0.017\end{array}$ & $\begin{array}{l}0.0019 \\
0.013\end{array}$ \\
\hline Co- 60 & $5.3 \mathrm{y}$ & $\begin{array}{l}\text { W: } \\
\text { Y: }\end{array}$ & $\begin{array}{l}0.036 \\
0.34\end{array}$ & $\begin{array}{l}\text { M: } \\
\text { S: }\end{array}$ & $\begin{array}{l}0.042 \\
0.16\end{array}$ & $\begin{array}{l}0.027 \\
0.088\end{array}$ \\
\hline Ru-106/Rh-106 & $368 \mathrm{~d}$ & $\begin{array}{l}\text { D: } \\
\text { W: } \\
\text { Y: }\end{array}$ & $\begin{array}{l}0.018 \\
0.21 \\
1.0\end{array}$ & $\begin{array}{l}\text { F: } \\
\text { M: } \\
\text { S: }\end{array}$ & $\begin{array}{l}0.0070 \\
0.17 \\
0.45\end{array}$ & $\begin{array}{l}0.0082 \\
0.090 \\
0.23\end{array}$ \\
\hline I- 129 & $1.6 \times 10^{7} y$ & D: & 0.0003 & F: & 0.00015 & 0.00020 \\
\hline $\mathrm{I}-131$ & $8.0 \mathrm{~d}$ & D: & 0.00065 & F: & 0.000064 & 0.000087 \\
\hline $\mathrm{I}-132$ & $2.3 \mathrm{~h}$ & D: & 0.00027 & F: & 0.000031 & 0.000038 \\
\hline Ce-144/Pr-144 & $284 d$ & $\begin{array}{l}\text { W: } \\
\text { Y: }\end{array}$ & $\begin{array}{l}0.18 \\
0.79\end{array}$ & $\begin{array}{l}\text { M: } \\
\text { S: }\end{array}$ & $\begin{array}{l}0.15 \\
0.35\end{array}$ & $\begin{array}{l}0.088 \\
0.19\end{array}$ \\
\hline
\end{tabular}


TABLE 5. Effective dose given by the Publication 66 respiratory tract model compared with Publication 61 (ICRP, 1991b) values.

\begin{tabular}{|c|c|c|c|c|c|c|}
\hline \multirow{3}{*}{$\begin{array}{l}\text { Radio- } \\
\text { nuclide }\end{array}$} & \multirow[b]{3}{*}{$t_{1 / 2}$} & \multicolumn{5}{|c|}{ Effective Dose per Unit Intake $(\mu \mathrm{Sv} / \mathrm{Bq})$} \\
\hline & & \multirow{2}{*}{\multicolumn{2}{|c|}{$\begin{array}{l}\text { Publication } 30 \text { Model } \\
\text { (by retention class) }\end{array}$}} & & \multicolumn{2}{|c|}{$\begin{array}{c}\text { Publication } 66 \text { Model } \\
\text { (by solubility type and AMAD) }\end{array}$} \\
\hline & & & & & $1-\mu \mathrm{m}$ & $5-\mu \mathrm{m}$ \\
\hline Po-210 & $138 \mathrm{~d}$ & $\begin{array}{l}\mathrm{D}: \\
\mathrm{W}:\end{array}$ & $\begin{array}{l}1 \\
2\end{array}$ & $\begin{array}{l}\text { F: } \\
\text { M: } \\
\text { S: }\end{array}$ & $\begin{array}{l}0.52 \\
3.3 \\
4.4\end{array}$ & $\begin{array}{l}0.62 \\
2.4 \\
3.2\end{array}$ \\
\hline U-234 & $244,500 \mathrm{y}$ & $\begin{array}{l}\text { D: } \\
\text { W: } \\
\text { Y: }\end{array}$ & $\begin{array}{c}0.4 \\
2 \\
40\end{array}$ & $\begin{array}{l}\text { F: } \\
\text { M: } \\
\text { S: }\end{array}$ & $\begin{array}{l}0.11 \\
3.3 \\
9.0\end{array}$ & $\begin{array}{l}0.13 \\
2.3 \\
7.1\end{array}$ \\
\hline Pu-239 & $24,000 \mathrm{y}$ & $\begin{array}{l}\text { W: } \\
\text { Y: }\end{array}$ & $\begin{array}{l}70 \\
60\end{array}$ & $\begin{array}{l}\text { M: } \\
\text { S: }\end{array}$ & $\begin{array}{l}53 \\
16\end{array}$ & $\begin{array}{l}37 \\
9.1\end{array}$ \\
\hline Am-241 & $432 \mathrm{y}$ & W: & 70 & M: & 55 & 38 . \\
\hline $\mathrm{Cm}-242$ & $163 \mathrm{~d}$ & W: & 4 & M: & 5.1 & 4.0 \\
\hline $\mathrm{Cm}-244$ & $18.1 \mathrm{y}$ & W: & 40 & M: & 33 & 23 \\
\hline P-32 & $14.3 \mathrm{~d}$ & $\begin{array}{l}\text { D: } \\
\text { W: }\end{array}$ & $\begin{array}{l}0.002 \\
0.004\end{array}$ & $\begin{array}{l}\mathrm{F}: \\
\mathrm{M}:\end{array}$ & $\begin{array}{l}0.00077 \\
0.0030\end{array}$ & $\begin{array}{l}0.0011 \\
0.0027\end{array}$ \\
\hline Co-57 & $271 d$ & $\begin{array}{l}\text { W: } \\
\text { Y: }\end{array}$ & $\begin{array}{l}0.0007 \\
0.002\end{array}$ & $\begin{array}{l}\text { M: } \\
\text { S: }\end{array}$ & $\begin{array}{l}0.00046 \\
0.00090\end{array}$ & $\begin{array}{l}0.00038 \\
0.00055\end{array}$ \\
\hline $\mathrm{Fe}-59$ & $44.6 \mathrm{~d}$ & $\begin{array}{l}\text { D: } \\
\text { W: }\end{array}$ & $\begin{array}{l}0.004 \\
0.003\end{array}$ & $\begin{array}{l}\mathrm{F}: \\
\mathrm{M}:\end{array}$ & $\begin{array}{l}0.0019 \\
0.0029\end{array}$ & $\begin{array}{l}0.0025 \\
0.0026\end{array}$ \\
\hline Co-60 & $5.3 \mathrm{y}$ & $\begin{array}{l}\text { W: } \\
\text { Y: }\end{array}$ & $\begin{array}{l}0.009 \\
0.06\end{array}$ & $\begin{array}{l}\text { M: } \\
\text { S: }\end{array}$ & $\begin{array}{l}0.0084 \\
0.027\end{array}$ & $\begin{array}{l}0.0065 \\
0.015\end{array}$ \\
\hline Ru-106/Rh-106 & $368 \mathrm{~d}$ & $\begin{array}{l}\text { D: } \\
\text { W: } \\
Y:\end{array}$ & $\begin{array}{c}0.02 \\
0.03 \\
0.1\end{array}$ & $\begin{array}{c}\text { F: } \\
\text { M: } \\
\text { S: }\end{array}$ & $\begin{array}{l}0.0080 \\
0.024 \\
0.057\end{array}$ & $\begin{array}{l}0.010 \\
0.016 \\
0.032\end{array}$ \\
\hline $\mathrm{I}-129$ & $1.6 \times 10^{7} \mathrm{y}$ & D: & 0.067 & F: & 0.056 & 0.077 \\
\hline I-131 & $8.0 \mathrm{~d}$ & D: & 0.013 & F: & 0.011 & 0.016 \\
\hline $\mathrm{I}-132$ & $2.3 \mathrm{~h}$ & D: & 0.00013 & F: & 0.00015 & 0.00024 \\
\hline Ce-144/Pr-144 & $284 \mathrm{~d}$ & $\begin{array}{l}\text { W: } \\
\text { Y: }\end{array}$ & $\begin{array}{l}0.05 \\
0.1\end{array}$ & $\begin{array}{l}\text { M: } \\
\text { S: }\end{array}$ & $\begin{array}{l}0.032 \\
0.045\end{array}$ & $\begin{array}{l}0.022 \\
0.027\end{array}$ \\
\hline
\end{tabular}




\section{REFERENCES}

Birchall, A.; Bailey, M. R.; James, A. C. LUDEP: A lung dose evaluation program. Radiat. Prot. Dosim. 38:167-174; 1991.

Egan, M. J.; Nixon, W.; Robinson, N. I.; James, A. C.; Phalen, R. F. Inhaled aerosol transport and deposition calculations for the ICRP Task Group. J. Aerosol Sci. 20:1305$1308 ; 1989$.

International Commission on Radiological Protection. Limits for intakes of radionuclides by workers. Oxford: Pergamon Press; ICRP Publication 30, Part 1; Ann. ICRP 2(3); 1979.

International Commission on Radiological Protection. Individual monitoring for intakes of radionuclides by workers: Design and interpretation. Oxford: Pergamon Press; ICRP Publication 54; Ann. ICRP 19(1/3); 1981.

International Commission on Radiological Protection. Age-dependent doses to members of the public from intakes of radionuclides: Part 1. Oxford: Pergamon Press; ICRP Publication 56 Ann. ICRP 20(2); 1989.

International Commission on Radiological Protection. 1990 Recommendations of the International Commission on Radiological Protection. Oxford: Pergamon Press; ICRP Publication 60; Ann. ICRP 21(1/3); 1991a.

International Commission on Radiological Protection. Annual limits on intakes of radionuclides by workers based on the 1990 recommendations. Oxford: Pergamon Press; ICRP Publication 61; Ann. ICRP 21(4); 1991 b. 
International Commission on Radiological Protection. Human respiratory tract model for radiological protection. Oxford: Pergamon Press; ICRP Publication 66; Ann. ICRP 24(1/4); 1994.

Jarvis, N. S.; Birchall, A; James, A. C.; Bailey, M. R.; Dorrian, M.-D. LUDEP 1.0:

Personal computer program for calculating internal doses using the new ICRP respiratory tract model. Chilton, Didcot, Oxon, UK: National Radiological Protection Board; NRPBSR264; 1993. 